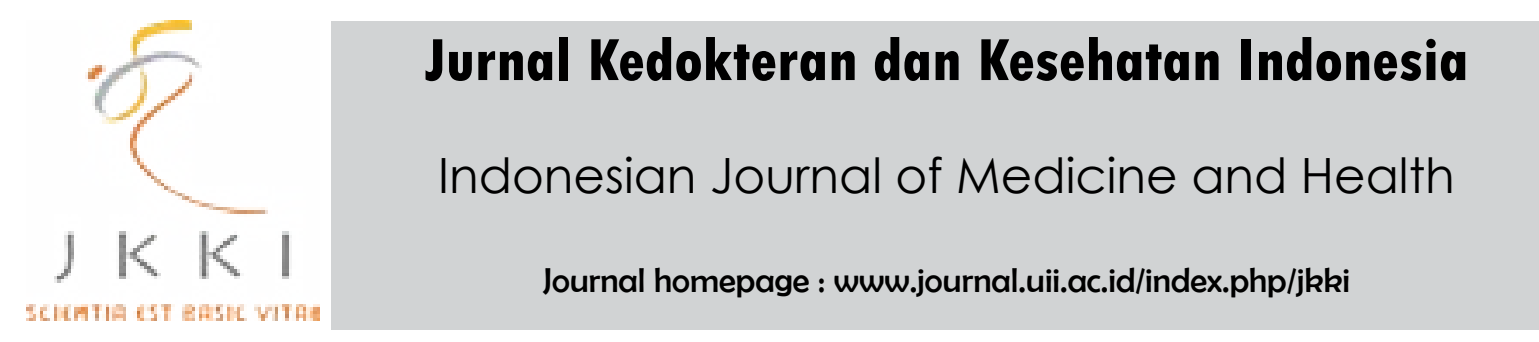

\title{
Recognize and prevent the transmission of virus zika
}

Asri Hendrawati ${ }^{1}$

${ }^{1}$ Faculty of Medicine, Islamic University of Indonesia

\begin{tabular}{l}
\hline ART ICLE INFO \\
\hline $\begin{array}{l}\text { *orresponding author: } \\
\text { asrixabi@yahoo.com }\end{array}$
\end{tabular}

DOI : 10.20885/JKKI.Vol7.Iss4.art1

\section{EDITORIAL}

7 ika virus is currently a highlight topic in the field of global health. Zika virus outbreaks in some countries including in

$\triangle$ Singapore have been making people worried and causing health official in any country to prevent Zika from becoming entrenched and spreading in population in the world. In 2016, it was reported a few countries in the Americas declared endemic Zika virus such as El Salvador, Venezuela, Colombia, Brazil, Honduras, Mexico and Panama. While countries in Asia, including Indonesia expressed as sporadic areas Zika virus. ${ }^{1}$

Zika virus is a virus that is transmitted through the bite of Aedes mosquito genus, the same as the genus of mosquitoes causing dengue fever and chikungunya. The virus can also be transmitted through sexual intercourse with an infected person Zika virus. About $20 \%$ of people infected with Zika virus has clinical symptoms such as fever, skin rashes, muscle and joint pains, headache and conjunctivitis. Zika virus incubation period of about $2-7$ days. ${ }^{2}$

Zika virus is a virus Flaviridae family that was first discovered the mosquito Aedes africanus in 1947 and allegedly did not attack humans. But later, it was found clinical symptoms in humans in 1953 which were caused by Zika virus in Nigeria. Antibodies in Uganda at that time showed approximately $6 \%$ of the population have antibodies to Zika virus. Examination of antibodies against the virus in humans were found positive in many countries today, such as in Egypt, South Africa, India, Malaysia and Indonesia. In Indonesia and another countries in Southeast Asia, the sporadic of Zika virus has been occurring for the last 6 years. ${ }^{3}$

Zika virus can not be taken lightly because it can cause death. Initial symptoms of Zika virus are similar to those of dengue fever and chikungunya, but fever and muscle or joint pain tend to be milder. In the Zika virus infection, the specific sign is a maculopapular rash with pruritus. Advanced symptoms of Zika virus infection may include swelling of the joints, mucosal bleeding and nervous system disorders. ${ }^{4}$ There is a relationship between Zika virus infection with the incidence of Guillain-Barré syndrome. Patients with the syndrome will experience motor paralysis caused by spinal nerve cell death that is progressive from the dorsal to the cranial. Eventually people with the syndrome may experience paralysis of the respiratory muscles that cause respiratory failure and death. Other causes of death for Zika virus infection is complicated by meningoencephalitis 
and acute myelitis. ${ }^{5}$

Diagnosis of Zika is based on symptoms, clinical signs and test results. Investigations need to do is to find the virus nucleic acid using real time PCR or detection of IgM anti Zika virus using ELISA. Diagnosis can be done in the first week of symptom onset. ${ }^{6}$

Nowadays, there is no vaccine or antiviral exists to prevent and therapy Zika. It is treated symptomatically and supportively. To prevent of transmission is only by avoiding mosquito bites, inhibiting the proliferation of mosquitoes, avoiding sexual contact from a person who has Zika. To reduce mosquito populations, there are several steps which can be implemented by not only professional such as government but also by community. This steps include conduct mosquito surveillance, remove places where mosquitoes lay eggs; at least once a week, items that hold water should be emptied, cleaned or thrown away if they are not used anymore, control young mosquitoes by removing standing water or using a larvicide, control adult mosquitoes by using adulticides and the last step is monitor all of steps to make sure that all of activities are working good. ${ }^{1}$

\section{REFERENCES:}

1. Centers for Disease Control and Prevention (CDC). Zika virus. 2016 http://www.cdc.gov/zika/ index.html.

2. Kutsuna S, Kato Y, Takasaki T, Moi ML, Kotaki A, Uemura H, Matono T, Fujiya Y, Mawatari M, Takeshita N, Hayakawa K, Kanagawa S, Ohmagari N. Two cases of Zika fever imported from French Polynesia to Japan, December 2013 to January 2014. Euro Surveill 2014; 9(4):50-3.

3. Petersen LR, Jamieson DJ, Powers AM, Honein MA. Zika Virus. N Engl J Med. 2016; 374:155263.

4. Karimi O, Goorhuis A, Schinkel J, Codrington J, Vreden SGS, Vermaat JS, Stijnis C, Grobusch MP. Thrombocytopenia and subcutaneous bleedings in a patient with Zika virus infection. Lancet 2016; 387: 939-40.

5. Rozé B, Najioullah F, Fergé J,Apetse K, Brouste Y, Cesaire R, Fagour C, Fagour L, Hochedez P, Jeannin S, Joux J, Mehdaoui H, Valentino R, Signate A, Cabie A. Zika virus detection in urine from patients with Guillain-Barré syndrome on Martinique, January 2016. Euro Surveill 2016; 21(9).

6. Lanciotti RS, Kosoy OL, Laven JJ, Velez JO, Lambert AJ, Johnson AJ, Stanfield SM, Duffy MR. Genetic and serologic properties of Zika virus associated with an epidemic, Yap State, Micronesia, 2007. Emerg Infect Dis 2008; 14: 1232-9. 